\title{
USDA-ARS National Sedimentation Laboratory: A Historic Perspective
}

\author{
Robert R. Wells', Sean J. Bennett ${ }^{2}$, Ronald L. Bingner ${ }^{1}$, Seth M. Dabney ${ }^{1}$, \\ Eddy J. Langendoen ${ }^{1}$, Henrigue G. Momm³ ${ }^{3}$ Mathias J. M. Römkens' ${ }^{1}$, Glenn V. Wilson'1 \\ ${ }^{1}$ Agricultural Research Service, United States Department of Agriculture, Oxford, USA \\ ${ }^{2}$ Department of Geography, University at Buffalo, Buffalo, USA \\ ${ }^{3}$ Department of Geosciences, Middle Tennessee State University, Murfreesboro, USA \\ Email: robert.wells@ars.usda.gov, seanb@buffalo.edu, henrique.momm@mtsu.edu
}

Received 28 January 2015; accepted 22 February 2015; published 25 February 2015

Copyright (C) 2015 by authors and Scientific Research Publishing Inc.

This work is licensed under the Creative Commons Attribution International License (CC BY).

http://creativecommons.org/licenses/by/4.0/

c) (i) Open Access

\begin{abstract}
Most authorities concede sediment from soil erosion to be the largest single stream pollutant. Physical damage from sediment includes reservoir storage loss, navigation channel filling, stream channel morphology alterations, ecological impacts, and clogging of drainage pathways. Ultimately, soil erosion is a very expensive problem. In the United States, accelerated soil erosion has been an ongoing issue since the establishment of the colonies. Through the initiative of great minds and the labor of countless individuals, the USDA was established and continues to fight for the people, providing assistance, guidance, and research. In this manuscript, the historical groundwork is laid for the establishment of the USDA-ARS National Sedimentation Laboratory (NSL) and a synopsis of NSL research is provided. This brief perspective of soil erosion research conducted on behalf of the people is but a small portion of the illustrious history of the USDA.
\end{abstract}

\section{Keywords}

Soil Erosion, Sedimentation, Ephemeral Gully, Water Quality, Modeling

\section{Historic Introduction}

\section{1. "The People's Department", United State Department of Agriculture (USDA)}

From humble beginnings, an idea of people helping people through sharing ideas and concerns, water and electricity, seeds and school lunches, the United States Department of Agriculture has and will always remain, a department for the people. First established as the Agricultural Division, Patent Office, Department of State in 1839, continued growth within the Department of the Interior (1849-1862), and expansion into a separate entity,

How to cite this paper: Wells, R.R., Bennett, S.J., Bingner, R.L., Dabney, S.M., Langendoen, E.J., Momm, H.G., Römkens, M.J.M. and Wilson, G.V. (2015) USDA-ARS National Sedimentation Laboratory: A Historic Perspective. Journal of Water Resource and Protection, 7, 228-246. http://dx.doi.org/10.4236/jwarp.2015.73019 
the Department of Agriculture (1862-1889) eventually achieved cabinet status in 1889 (Table 1).

Impetus for the creation of an Agricultural Division began with President George Washington. In his final address to Congress, 1796, he proposed the establishment of an Agricultural Board that would collect experimental results and observations, and pass the information on to the appropriate officials in the States. By 1825, both the House of Representatives (1820) and the Senate had established agricultural committees. Potentially one of the first influential lobbying groups, the United States Agricultural Society was formed (1852) to direct official interest to the agricultural needs of the time. President Abraham Lincoln signed an Act establishing the United States Department of Agriculture in 1862. The purpose of the Department was:

"to acquire and diffuse among the people of the United States useful information on subjects connected with agriculture in the most general and comprehensive sense of that word, and to procure, propagate, and distribute among the people new and valuable seeds and plants." (Lincoln, 1862)

The Department of Agriculture was organized under the leadership of Commissioner Isaac Newton. Annual reports were generated by the Commissioner to the President for the purpose of reporting agricultural statistics, seed collections and distributions, report on regional crops, and use of chemicals in agriculture. In his first commissioner's report to President Lincoln, Newton wrote:

"Agriculture furnishes the food of the nation, the raw materials of manufactures, and the cargoes of domestic and foreign commerce. It is the cause and the evidence of true civilization; for, when tillage begins barbarism ends, and the various arts commence. When agriculture prospers, all other interests prosper."

The birth of the Department of Agriculture preceded the Homestead and Morrill Acts by only a few months. The Homestead Act granted government lands to small farmers at a low price and the Morrill Act established land-grant colleges for the benefit of agriculture. Both pieces of legislation have been key to the long-term efficacy of sustainable agriculture. In 1875, the first agricultural experiment station was established at Wesleyan University, CT. In 1887, the Hatch Act provided for the federal funding of agriculture experiment stations in each state and in 1888, the Office of Experiment Stations was established within the Department of Agriculture. The seventh Commissioner of Agriculture, Norman Coleman, in his annual report to the President in 1888 wrote:

"The Department of Agriculture can aid the experiment stations in their relations to each other, in their use of the results of experimental research, and in their connection with the agricultural public. To be first among the stations the Department should be the servant of them all. It should exercise not dictatorship, but leadership. Its influence should be powerful in bringing the stations together in coordinating their work; in making the fruits of other research and experience, past and present, at home and abroad, available to them; in prosecuting lines of pioneer research which will in a measure relieve the stations of a difficult but necessary task, and enable them to apply their energies more fully and successfully to the study of the questions which bear directly upon the practice of agriculture; in collating, condensing, and distributing their results, and in helping to carry the practical outcome to the farmer in a form in which he will appreciate and use."

Under pressure from advocacy groups, the United States Department of Agriculture (USDA) was given cabinet status in 1889 by President Grover Cleveland, and the first Secretary of Agriculture was Norman Coleman. In 1890, the second Morrill Act was passed, which stipulated states that maintained separate colleges for different races would equitably divide land-grant funds. Also during this time, the USDA began a series of Farmers' Bulletins that were used as a vehicle of information dispensation of the various Bureaus and Offices of the Department. These bulletins reached out to the people and conveyed the agricultural discoveries and observations of the time.

During the period 1862 to 1929, the USDA experienced major expansion in program activities and areas of responsibility. USDA had grown from a small division in the Patents Office that primarily collected and dispersed seeds to a cabinet Department that carried out agricultural research in irrigation, land drainage, hydrology, and agronomy, as well as responsibility for the protection of National Forest lands and licensing the use of water for the production of power. Activities within the Department had established the fact that land and water cannot be separated, since all surface runoff is derived from the land and all fresh water recharge must pass through the soil. The Department, therefore, had achieved a stature and scope that permitted it to fulfill future responsibilities in the field of water resources development. 
Table 1. Select timeline of soil erosion history in the United States and popular culture.

\begin{tabular}{|c|c|}
\hline Year & Precedent \\
\hline 1789 & Congress creates Departments of State, Treasury, and War. \\
\hline 1793 & Invention of cotton gin. \\
\hline 1825 & $\begin{array}{l}\text { Agriculture Committee, U.S. House of Representative established. } \\
\text { Agriculture Committee, U.S. Senate established. }\end{array}$ \\
\hline 1835 & $\begin{array}{l}\text { Henry Leavitt Ellsworth, appointed U.S. Commissioner of Patents; began collecting and distributing new varieties of seeds; } \\
\text { known as founder of what became the USDA. }\end{array}$ \\
\hline 1839 & $\begin{array}{l}\text { Agricultural Division, Patent Office, Department of State: Compile agricultural statistics, collect and distribute seeds, report } \\
\text { on regional crops, and use of chemicals in agriculture. }\end{array}$ \\
\hline 1849 & $\begin{array}{l}\text { Agricultural Division, Patent Office, Department of the Interior: creation of new department to handle domestic matters; } \\
\text { transfer of Ag. Div. with similar functions. }\end{array}$ \\
\hline 1852 & United States Agricultural Society formed. \\
\hline 1860 & Farmers made up $58 \%$ of the labor force. \\
\hline 1862 & $\begin{array}{l}\text { Agricultural Act: United States Department of Agriculture established; President Lincoln, in an address to Congress, called } \\
\text { the USDA the "People’s Department”. } \\
\text { Homestead Act: grant public land to small farmers at low cost. } \\
\text { Morrill Act: establish land-grant colleges for the benefit of agriculture. }\end{array}$ \\
\hline 1870 & Farmers made up $47 \%$ of the labor force. \\
\hline 1875 & First state agricultural experiment station established at Wesleyan University, CT. \\
\hline 1879 & Creation of U.S. Geological Survey within Department of the Interior. \\
\hline 1880 & Farmers made up $49 \%$ of the labor force; 1 in 4 were tenant farmers. \\
\hline 1887 & Hatch Act: set up federal-state cooperation in agricultural research. \\
\hline 1888 & Office of Experiment Stations established. \\
\hline 1889 & $\begin{array}{l}\text { USDA moved to Executive branch and given cabinet status. } \\
\text { Soil Survey established within Weather Bureau of USDA. }\end{array}$ \\
\hline 1890 & $\begin{array}{l}\text { Morrill Act: established equitable divisions of land grant funding for blacks; } 16 \text { new colleges were created in the South. } \\
\text { Farmers made up } 43 \% \text { of the labor force. }\end{array}$ \\
\hline 1894 & $\begin{array}{l}\text { Division of Agricultural Soil established in Weather Bureau of USDA. } \\
\text { Farmers' Bulletin No. 20: "Washed soils: How to prevent and reclaim them" by Charles Dabney; milestone publication in } \\
\text { soil conservation. }\end{array}$ \\
\hline 1899 & Field mapping of soils began by USDA. \\
\hline 1900 & Farmers made up $38 \%$ of the labor force. \\
\hline 1903 & Wilbur and Orville Wright airplane flight (longest trial is 59 seconds and 852 feet). \\
\hline 1908 & T. C. Chamberlain gives talks on "soil wastage". \\
\hline 1910 & Farmers made up $31 \%$ of the labor force. \\
\hline 1911 & First Farm Bureau formed in Broome County, NY. \\
\hline 1914 & Smith-Lever Act: sets up national extension service. \\
\hline 1920 & $\begin{array}{l}\text { Farmers made up } 27 \% \text { of the labor force. } \\
\text { Soil classification system developed. }\end{array}$ \\
\hline 1925 & Purnell Act: authorized funds to experiment stations for research on the economic and social problems in agriculture. \\
\hline 1928 & $\begin{array}{l}\text { Soil erosion is identified as a serious threat to agricultural productivity. } \\
\text { Mc Sweeney-Mc Nary Forest Research Act: authorized USDA to conduct research on favorable conditions of water flow } \\
\text { and the prevention of erosion. } \\
\text { Buchanan Amendment: provided first Congressional appropriation to set up experiment stations to conduct soil erosion } \\
\text { research operated by USDA. } \\
\text { Circular 33: Soil Erosion, A National Menace published by Hugh Hammond Bennett and W.R. Chapline. } \\
\text { Model A automobile launched. }\end{array}$ \\
\hline
\end{tabular}




\section{Continued}

1930 Farmers made up 22\% of the labor force.

1932

Dust Bowl: persistent drought conditions on the Great Plains caused widespread crop failures and exposed the region's soil to blowing wind.

1933 National Industrial Recovery Act: Soil Erosion Service (SES) established in Department of the Interior; Hugh Hammond Bennett, "father of soil conservation”, was named Chief.

Dust storm on May 11, 1934 swept fine soil particles over Washington, D.C. and three hundred miles out into the Atlantic Ocean.

On March 6 and again on March 21, 1935 dust clouds passed over Washington, D.C. and darkened the sky just as Congress commenced hearings on a proposed soil conservation law. Hugh Hammond Bennett holds court with Congress.

1935 Soil Conservation and Domestic Allotment Act: SES moved to USDA and renamed Soil Conservation Service (SCS); Hugh Hammond Bennett named Director. Bankhead-Jones Act: provided expansion of agricultural research.

Concept of vegetative waterways developed to channel runoff and prevent gully erosion.

1936 Flood Control Act: determine the most effective methods to control erosion and prevent floods.

1937 First soil conservation district organized in Brown Creek watershed, Anson County, NC.

$1940 \quad$ Farmers made up 18\% of the labor force; 2 in 5 were tenant farmers.

1942 Agricultural Research Administration (ARA) established within USDA.

1944 Flood Control Act: SCS begins work on 11 watershed projects.

SCS initiates upstream land treatment through the Yazoo-Little Tallahatchie (Y-LT) Project.

1948 A small-scale research project was initiated by the SCS at State College, MS (now Mississippi State University). Saint Anthony Falls stilling basin designed (Minneapolis, MN).

$1950 \quad$ Farmers made up $11 \%$ of the labor force.

1953 Agricultural Appropriations Act: SCS given 63 additional watershed projects. Agricultural Research Service (ARS) division of USDA is created; SCS transfers research activities.

1954 Watershed Protection and Flood Prevention Act: Congress gave SCS permanent watershed planning authority. ARS consolidates research projects of Y-LT within Soil and Water Research Conservation Division.

Congress appropriates funds for sedimentation research; Y-LT/ARS research moved to Oxford, MS; temporarily housed on campus of University of Mississippi.

Funds appropriated for Sedimentation Laboratory in Oxford, MS.

1957 Civil Rights Act.

Sputnik launched.

$1958 \quad$ Universal Soil Loss Equation (USLE) developed.

$1970 \quad$ Less than $5 \%$ of the labor force is made up of farmers.

$1971 \quad$ Microcomputers invented.

1980 CREAMS: A Field Scale Model for Chemicals, Runoff and Erosion from Agricultural Management Systems published.

1989 Water Erosion Prediction Project (WEPP) developed.

1995 Revised Universal Soil Loss Equation (RUSLE) completed.

\subsection{Natural Resources Conservation Service (NRCS)}

The USDA Bureau of Soils began to make county-based soil surveys in 1899. Amid cumulative evidence highlighting erosion within the states, Chief Milton Whitney, Bureau of Chemistry and Soils, published Bulletin 55, in which he related that:

"The soil is the one indestructible, immutable asset that the Nation possesses. It is the one resource that cannot be exhausted; that cannot be used up."

Perhaps presumptive or naïve, more likely politically calming in nature, statements and thoughts of this type 
were and, in some cases, continue to flourish. Still, in 1910, a field party consisting of three members of the Mississippi Geological Survey and two USDA Bureau of Soils surveyors, Hugh H. Bennett and Howard C. Smith, completed a survey of Lauderdale County, Mississippi [1]. This survey identifies an "erosion phase" of Orangeburg sandy loam, designating a soil not as a distinct soil type, but as a soil that is modified by erosion. They assert through classification that the soil difference was the result of erosion. Reports of excessive erosion in South Carolina [2] and Georgia [3] were made by Hugh H. Bennett, further expressing the need for federal involvement in this pivotal problem area. USDA Bulletins 71 [4], 180 [5], and 512 [6] document the principles underlying soil erosion, the devastation caused by soil erosion in the southern United States, and soil erosion prevention measures, respectively. Chief of the Bureau of Chemistry and Soils, Henry G. Knight, placed Hugh $\mathrm{H}$. Bennett in charge of a special study of the extent of soil erosion and methods of control, effective January 1928. Later that same year, Bennett's best-known publication of the period was published, "Soil Erosion, A National Menace" [7]. Written with the help of W. R. Chapline of the U.S. Forest Service, the circular was regarded as more effective than previous erosion bulletins because it was not technical and did not discuss erosion control measures. Instead, coming shortly after the great Mississippi flood of 1927, Bennett and Chapline's bulletin emphasized only the damages caused by erosion and the need for action to stop erosion. Owing to this growing concern over soil erosion, in 1928, two instrumental pieces of legislation were passed: McSweeneyMcNary Forest Research Act (authorized research on erosion prevention) and Buchannan Amendment (funds were appropriated for soil erosion investigations and regional soil erosion experiment stations). The locations selected for the Regional Soil Erosion Experiment Stations were as follows:

Batesville, Arkansas; Tifton and Watkinsville, Georgia; Dixon Springs, Joliet, and Urbana, Illinois; Lafayette, Indiana; Clarinda, Cortana, Beaconsfield, Independence, and Seymour, Iowa; Hays, Kansas; Baton Rouge, Louisiana; Presque Isle, Maine; Benton Harbor and East Lansing, Michigan; Holly Springs and State College, Mississippi; Bethany and McCredie, Missouri; Hastings, Nebraska; Bumerville, Marlboro, and New Brunswick, New Jersey; Ithaca, Geneva, and Marcellus, New York; Statesville and Raleigh, North Carolina; Coshocton and Zanesville, Ohio; Cherokee and Guthrie, Oklahoma; Clemson and Spartanburg, South Carolina; Knoxville and Greenville, Tennessee; Temple and Tyler, Texas; Blacksburg, Virginia; Pullman, Washington; Lacrosse, Madison, and Owen, Wisconsin; and Mayaguez, Puerto Rico.

A short time later, 1933, the National Industrial Recovery Act established the Soil Erosion Service (SES) within the Department of the Interior. Hugh H. Hammond, now regarded as the nation's soil erosion expert, was named the first SES Chief. The SES was an emergency/temporary agency set up to administer unemployment relief funds used for erosion control and conduct a national reconnaissance erosion survey. In a move of brilliant political strategy, Hugh H. Hammond successfully convinced Congress and the President that soil conservation was of the utmost importance. In 1935, under the Soil Conservation Act, the SES was moved to the USDA, made a permanent agency within the government, and renamed the Soil Conservation Service (SCS) with Hugh H. Bennett as director. For a brief period, 1942-1945, Executive Order 9280 consolidated the SCS with a few other agricultural Bureaus and Offices to form the War Food Administration, with the mission to meet wartime food requirements.

In 1994, Congress initiated a major reorganization of the USDA and renamed SCS the Natural Resources Conservation Service (NRCS) to better reflect the broad scope of the agency's mission. These changes marked the beginning of two major trends that have defined the Service's role in conservation since: responsibility for administering financial assistance for conservation programs and substantial increases in the amount of financial assistance available for conservation. The result over the last two decades has been rapid growth in innovative programs that give conservationists and landowners the necessary means to protect our nation's natural resources.

\subsection{Agricultural Research Service (ARS)}

Executive Order 9069, 1942, consolidated certain agencies within the USDA and established the Agricultural Research Administration (ARA). The ARA functioned chiefly to coordinate research activities of the Bureaus of Agricultural Chemistry and Engineering, Animal Industry, Dairy Industry, Entomology and Plant Quarantine, Home Economics, and Plant Industry; and the Office of Experiment Stations. Two important changes occurred in 1953: 1) Secretary's Memorandum 1320, abolished the ARA and the various independent Bureaus it served, 
transferred forest disease and entomology functions to the Forest Service, and transferred non-forest research functions to the Agricultural Research Service (ARS); and 2) Secretary's Memorandum 1318, abolished the SCS's Office of Research and transferred responsibility for soil erosion research functions to the ARS. ARS also exercised supervision over the Office of Experiment Stations until separation as the Cooperative State Experiment Station Service (CSRS) in 1961. ARS consolidated with CSRS, Extension Service, and National Agricultural Library by Secretary's order in 1978 to form the Science and Education Administration (SEA). ARS functions were assigned to the Federal Research Staff, re-designated Agricultural Research Staff in 1979. Secretary's Memorandum 1000-1 abolished the SEA, and the ARS and other components were re-established in 1981.

The Agricultural Research Service is the principal in-house research agency of the United States Department of Agriculture. ARS is one of four agencies in USDA's Research, Education and Economics mission area and is charged with extending the nation's scientific knowledge and solving agricultural problems through its four national program areas: nutrition, food safety and quality; animal production and protection; natural resources and sustainable agricultural systems; and crop production and protection. ARS research focuses on solving problems affecting Americans every day.

The National Program of ARS to which the theme of the present work serves is NP 211: Water Availability and Watershed Management. This national program seeks information regarding processes that control water availability and quality that may be used to improve water resources management. The overlying theme of the program is that water is fundamental for sustained health of society and the environment.

\subsection{USDA-ARS National Sedimentation Laboratory (NSL)}

Go west and prosper was the sentiment of early American settlement. Following the Treaty of Pontotoc in 1832, north Mississippi was opened to homesteading. Early homesteaders found dense forests and clear streams. At first the settlers cultivated only the fertile bench lands along the streams. Pressure for cropland led to clearing and plowing of steep, highly erodible soils. The agriculture system itself was exploitative and the chosen crops invited land deterioration. The clean, tilled crops of cotton and corn left the erodible soil exposed year round. Rain and gravity did the rest. As early as 1850, the state geologist made comments concerning severe erosion problems in northern Mississippi. Following the Civil War, cropland pressures increased and so did soil loss. Hillside after hillside was abandoned to the ravages of erosion. Large gullies and sediment-choked streams were commonplace. The serious lack of concern for and knowledge of our soil resource had left the land and the people destitute.

The Flood Control Act of 1944 named 11 watersheds throughout the United States for monitoring and authorized public works to improve them. By far, this is recognized as the most important piece of federal flood control legislation in the nation's and in Mississippi's history. This legislation explicitly committed the federal government to massive flood control work and provided strong impetus for establishing research facilities throughout the United States. In Mississippi, the Yazoo-Little Tallahatchie (Y-LT) Flood Prevention Project (1948-1985) was launched in 1947. Congress appropriated money to the SCS where the main objectives, as defined by law, were the reduction of floodwater and sedimentation damage, proper land use, channel stabilization, and improvement of affected local economies. The SCS allocated funds to the Forest Service (FS) who carried on the largest tree-planting program in US history to rehabilitate eroding lands in north Mississippi. Over a time span of 20 years, some 450,000 acres were transplanted with 550,000,000 Loblolly pine seedlings [8].

To assist in the design and to obtain evaluation data for the Y-LT project, a small-scale research project was initiated in 1948 by the SCS at State College (now Mississippi State University), MS. This project consisted primarily of sediment gauging of streams. However, as early as 1928, soil erosion studies were being conducted at Holly Springs and State College, MS; and, in 1953, soil erosion research was transferred from the SCS to the ARS (Secretary's Memorandum 1318). The USDA Sedimentation Laboratory originated as an extension of studies of soil erosion, gully formation, channel instability, and other sedimentation-related phenomenon that began in Holly Springs and State College, MS. Under the direction of Russell Woodburn (Table 2), these projects together with other research programs were consolidated in 1954, and assigned to the Soil and Water Research Conservation Division of the newly established Agricultural Research Service. Funds for the new Laboratory were appropriated in 1957 and the construction was completed in the fall of 1959. Senate Document No. 59, 86th Congress states the purpose of the Laboratory. 
Table 2. USDA-ARS-NSL directors.

\begin{tabular}{cc}
\hline Year & Director \\
\hline $1956-1961$ & Russell Woodburn \\
$1961-1963$ & Carl Miller \\
$1963-1969$ & Donald Parsons \\
$1969-1974$ & August Robinson \\
1974 & Roger McHenry (acting) \\
$1974-1978$ & Donn De Coursey \\
$1978-1979$ & Roger McHenry (acting) \\
$1979-1981$ & Donn De Coursey \\
$1981-1988$ & Neil Coleman \\
$1988-1992$ & Calvin Mutchler \\
$1992-1996$ & George Foster \\
$1996-1998$ & Mathias Römkens (acting) \\
$1998-2014$ & Mathias Römkens (recently retired) \\
\hline
\end{tabular}

\section{Sedimentation Laboratory, Oxford, MS}

"Knowledge of the amount of sediment transported in waterways and deposited in structures for impounding runoff and of the mechanics of sediment transportation and deposition is essential for the proper development of programs for watershed protection. Sediment transport is a complex process, and studies of this problem require unique facilities and competence. Since a major effort within the USDA is directed toward assisting local groups with watershed protection projects, the Department should maintain the necessary supporting program on sedimentation research.

The Sedimentation Laboratory currently being constructed will provide the necessary national center for sedimentation research. It should be emphasized that in order for this laboratory to operate effectively it will need to be fully staffed and adequately supported. Provisions should be made for research workers located outside the USDA to come to the Laboratory on temporary assignments to use the new facilities. The Oxford Laboratory can also serve as a center for field research on sedimentation in the critical southern loess hills area. The research program at the Laboratory will include an attack on the fundamental physics and fluid mechanics problems involved in sediment transport and deposition. Work also will be directed toward development of sediment instrumentation for measuring the amounts of sediment carried by streams and deposited in reservoirs."

The original Sedimentation Laboratory building was $2137 \mathrm{~m}^{2}$ that included office space, a large hydraulics laboratory, shop facilities, and laboratories for sediment, chemical and radiochemical analysis. In 1969, the Sedimentation Laboratory was expanded by the addition of $1858 \mathrm{~m}^{2}$ that included more office space, a second large hydraulics laboratory, several new chemical laboratories and a $952 \mathrm{~m}^{2}$ outdoor test channel. The last expansion was in 1986 where new chemical laboratories and office space were added. Great tribute must be given to the late Mississippi Congressman, Mr. Jamie Whitten, of the $1^{\text {st }}$ Congressional District, who had the foresight, the will, and the power to address this cause. The USDA-ARS Sedimentation Laboratory was designated USDA-ARS National Sedimentation Laboratory (NSL) in 1987 [9].

The mission of the NSL is to seek solutions to soil erosion and sedimentation related problems with emphasis on problems associated with the agricultural use of lands. The laboratory is specifically charged with seeking, through fundamental and applied research, for better methods of a) improving soil and water quality; b) controlling erosion and sedimentation; and c) conserving and managing agricultural land and water resources. The 
laboratory is further charged with communicating its findings through various scientific and technical publications, from which the research information generated is put to use by operational agencies concerned with soil erosion and sedimentation, such as the USDA NRCS.

Prior to the appointment of Director August R. Robinson (Table 2) in 1969, there was essentially no formal organization of the staff. Some obvious organizational and functional difficulties prompted Robinson to organize the Sedimentation Laboratory into research groups, although the number of research Units and names have changed from time to time. Presently, the NSL is directed by Mathias J.M. Römkens (Table 2) and has two Research Units: Watershed Physical Processes (Seth M. Dabney, Research Leader) and Water Quality and Ecology (Martin A. Locke, Research Leader). Current listing of professional staff is provided in Table 3.

\section{Research at the NSL}

\subsection{Nationwide Reservoir Sedimentation Survey and Nuclear Applications Technology}

Sedimentation surveys in more than 1200 reservoirs across the nation were made in cooperation with the committee on sedimentation of the USGS Water Resources Council. Also, in northern Mississippi Dr. Stanford Happ reactivated long-term valley aggradation studies initiated by the SCS in the mid-1930s to determine aggradation rates since land cultivation had shifted from the hills to the valleys during the intervening period. In 1968, research began on the application of fallout radionuclides to determine sediment deposition and soil redistribution rates and patterns in agricultural and natural ecosystems. This research was based on the use of fallout Cesium-137 (Cs-137) from nuclear weapon tests in the 1950s and 1960s that injected Cs-137 into the stratosphere that subsequently re-deposited on the landscape in uniform patterns related to precipitation patterns [10]. Once Cs-137 reaches the soil surface, it is strongly and quickly adsorbed by soil particles and is essentially nonexchangeable [11]. The distribution of fallout derived Cs-137 and its usefulness for dating sediment deposits was the focus of [12]-[15]. The unique advantages of using the Cs-137 technique to study soil erosion are that it a) requires a single sampling trip to the field; b) provides results quickly; c) allows retrospective assessment of soil erosion rates (average losses for 35 - 40 years period thus is less influenced by extreme events); d) provides estimates of soil erosion rates, deposition rates, and export rates; and e) allows a sampling strategy to provide any spatial resolution required [16]. More recently, a combination of radiometric techniques was used in [17], to identify the time history of Sky Lake, a Mississippi River oxbow cutoff near Belzoni, MS. A main conclusion of the study was that sedimentation rates in the lake have increased dramatically since land clearing in the late 19th century. In slightly more than a century since land clearing began, a thickness of sediment equivalent to that laid down over the previous several millennia was added, doubling the total sediment thickness. Radioisotope data and recent observations of sediment accumulation over the past 5 years indicate that the 50 -fold increase in sediment accumulation rate continues unabated.

Table 3. Current professional staff listing for the NSL.

\begin{tabular}{ccc}
\hline \multicolumn{2}{c}{ Mathias Römkens } & Director \\
\hline Watershed Physical Processes & Position & Water Quality and Ecology \\
\hline Seth M. Dabney & Research Leader & Martin A. Locke \\
Ronald L. Bingner & Agricultural Engineer & Michael B. Jenkins \\
James V. Bonta & Res. Hydraulic Engineer & Scott S. Knight \\
Roger A. Kuhnle & Res. Hydraulic Engineer & Richard E. Lizotte, Jr. \\
Eddy J. Langendoen & Res. Hydraulic Engineer & Mathew T. Moore \\
James R. Rigby & Res. Hydrologist & Jason M. Taylor \\
Robert R. Wells & Res. Hydraulic Engineer & Res. Ecologist \\
Glenn V. Wilson & Res. Hydrologist & Res. Ecologist \\
Daniel G. Wren & Res. Hydraulic Engineer &
\end{tabular}

\footnotetext{
*Split Appointment with WQERU.
} 


\subsection{Pesticide Research and Water Quality}

In the early 1970s, nationwide environmental concerns also impacted the research program at the Sedimentation Laboratory. A number of pesticide studies were conducted in the late 1960s and 1970s concerning the presence of chlorinated hydrocarbon insecticides in streambed sediment of the Mississippi River and its tributaries in Arkansas, Louisiana, Tennessee and Mississippi. The scope of research concerning pesticides effect on the ecosystem and pesticide persistence in and wash-off from canopies as affected by weather variables, application methods, formulation, and time after application broadened over the years. Research activities at the NSL began to include ecological impacts of conservation practices [18] [19] and residual pesticide persistence [20] [21]. Through these activities, water quality research began to evolve from conventional ecological surveys and assessments to more impact-oriented agricultural contaminant fate and effects studies. Researchers at the NSL began to look at the entire watershed system and evaluate ecosystem function within the watershed as affected by agricultural activities. Over the years, research focused on habitats within constructed erosion-control structures [22], wetland systems as filters for agricultural waste [22] [23], ecological integrity and streambank rehabilitation [24] [25], ecological impacts of conservation practices [26], drainage ditches as a new best management practice [27]-[29], and non-point source mitigation through hydrologic modification [30].

\subsection{Soil Erosion Research}

Throughout the years, the laboratory has maintained a continuous effort to quantify the processes and impacts of soil erosion. Research in this area was and continues to be conducted in both field and laboratory settings. Scientists and collaborators have studied soil loss related to crop and/or residue management [31]-[34], soil erodibility [35]-[42], effect of landscape features [43], erosion control [44] [46], rill erosion mechanics [47]-[49], sediment size distribution [50] [51], and sediment size distribution prediction [52]-[54]. Various ancillary studies were also conducted to quantify impacts of related physical processes, e.g. infiltration [55]-[57], surface seals [58] [59] and surface roughness effects [60]-[63].

\subsection{Gully Erosion Research}

Gullying occurs in every state within the United States and has been a central issue for the US government since its inception. Besides ruining fertile land, gullies interfere with farm operations, undermine buildings, encroach on public highways, endanger the life of stock, and often ruin the beauty and lower the market value of a farm. Gullies are also largely responsible for filling reservoirs and streams with sediment, and for covering once fertile bottomlands with deposits of sand. Early research activities [64]-[66], primarily focused on descriptive characteristics of gullies in the South, rates of sediment production, downstream impacts and conservation measures to control them. Headcut erosion, a primary process in gullies, is caused by the falling of water over the edge of a gully. The edge is washed away and caves in, owing to the undermining action of the falling water, and the waterfall moves back upstream. The undermining goes on rapidly when sand or easily eroded subsoil saturated with seepage water underlies the surface soil. Ephemeral gully erosion was first described as a distinct erosion phenomenon a few decades ago. This type of gully had previously been categorized as rills, as both were obliterated by routine tillage operations (unlike classic gullies which were not repairable by tillage). Research objectives during the 1980's and 1990's not only was concerned with quantifying rates of erosion but also turned toward prediction of concentrated flow erosion [67]-[72] and remote sensing technologies [73]. Foster [74] noted that while rills on hillslopes did not tend to reform in the same location, those located in the thalweg between hillslopes were persistent, perennial features that were only obscured by tillage and reformed in the same location year after year. While they fit the definition of a rill, they behave hydraulically as a larger channel and should be treated as individual channels in erosion analyses and modeling efforts [75]. More recently, studies have been conducted that include effects of slope [76], discharge [77], initial step height [78], conservation measures [79], soil stratification [80], soil type [81], tail-water and pore-water [82], imposed upstream sediment loads [83], channel width adjustment [84], and soil pipes [85]-[87]; as well as model technology [88]. Also, in cooperation with NRCS, NSL researchers assisted in the preparation of a document that described ephemeral gully erosion, current research activities and modeling technologies [89].

\subsection{Sediment Transport Research}

Laboratory research on sediment transport over the years have included topics such as the initiation of motion of 
sediment [90], suspended sediment transport [91]-[94], bed load transport [90], bed forms [95]-[97], local scour [98] [99], prediction of sediment loads in streams [100] [101], and physical processes of sediment transport [102]-[104]. Field studies of flow and sediment movement have been conducted on experimental watersheds and have provided baseline data on the movement of sediment in field channels. While these studies have yielded valuable data on the effect of land management practices on runoff and sediment yield as well as important data sets for watershed model development and validation, the fundamental attributes of the transport of sediment by flowing water are difficult to study in the field. In recent years, cooperative research projects with the National Center for Physical Acoustics (NCPA) have yielded instruments that use acoustic backscatter to collect information on suspended sediment concentrations in laboratory flumes [105]-[107]. Established in 1989 by Congressional Act, NCPA is located on the University of Mississippi campus and maintains basic and applied research programs in many areas of physical acoustics. NCPA investigates a variety of acoustic phenomenon, from ultrasonic to infrasonic. The porous media group is focused acoustic/laser imaging and detection as well as agriculture related projects with the USDA and additional research addresses areas specifically important to Mississippi, such as catfish health, termite and fire ant infestations and viability of flood control dams. For more information about NCPA, please visit http://ncpa.olemiss.edu/.

\subsection{Field and Watershed Modeling}

The NSL is the custodian of three computer-based models-The Revised Universal Soil Loss Equation (RUSLE; [108]), which is a computer program that initiates rates of soil erosion caused by rainfall and overland flow on upland areas (agricultural land, construction site, etc.); the Agricultural Non-Point Source Pollution (AGNPS; http://go.usa.gov/KFO; [109]) model, a computer model that predicts non-point source pollutant loadings within agricultural watersheds and includes erosion and sediment transport of the stream system; and the Conservation Channel Evolution and Pollutant Transport System (CONCEPTS;

http://www.ars.usda.gov/Research/docs.htm?docid=5453; [110]-[112]), a process-based computer model of instream and riparian processes that includes the effect of sediment generation due to channel bed changes and modifications. Recently, RUSLE2 (for details see http://www.ars.usda.gov/Research/docs.htm?docid=6010) was completed.

The National Center for Computational Hydroscience and Engineering (NCCHE) is a research unit of the School of Engineering at the University of Mississippi in Oxford, MS. NCCHE is funded through Congressional mandate with primary support from USDA-ARS and more recently through support by the Department of Homeland Security. The mission of the center is to advance the understanding of fundamental characteristics and develop modeling technologies of water flow, soil erosion, sediment transport phenomena and their effect on water resources, soil conservation, flood control, waterways safety as well as their impact on the environment/ ecology; educate future professionals through graduate degrees in Engineering Science; assist government agencies in carrying out research; and promote knowledge exchange through publications and other related activities. The computational models developed by the research members of NCCHE apply to the following areas:

- Free Surface Turbulent Flows (1D, 2D, 3D, and Unsteady)

- Sediment/Contaminant Transport (1D, 2D, 3D and Unsteady)

- Water Quality (with chemical kinetics and fate processes)

- Watershed Management Decision Support Systems

- Ecological and Environmental Impact Assessments

- Ground Water and Surface Water Interactions

- Dam-Break/Levee-Breach Flooding and Simulations

- Multi-Objective and Multi-Constraint Optimizations

- Coastal Processes with Current, Wave and Storm Surge Effects

All models developed at NCCHE have been rigorously tested by the comprehensive verification and validation procedure developed by the ASCE-EWRI Task Committee. For more information about NCCHE, please visit http://www.ncche.olemiss.edu/.

\subsection{Pigeon Roost Watershed}

The early research activities at the NSL represented a continuation of previous work conducted prior to its establishment. Among those were sediment sampling at twelve discharge stations in the $117 \mathrm{mi}^{2}$ Pigeon Roost 
Creek Watershed (PRCU). This work was designed to determine runoff and sediment production for several differing watershed conditions relative to land use and conservation practices. These measurements were made from 1950-1979 on drainage areas ranging from 100 acres to $117 \mathrm{mi}^{2}$. This study has provided a large data base on sediment movement that has been widely used in the development of sediment transport equations in channels.

\subsection{Demonstration Erosion Control (DEC)}

The Goodwin Creek Experimental Watershed (GCEW) near Batesville in North Central Mississippi was established as part of the Demonstration Erosion Control (DEC) project [113]-[117]. The project was designed to evaluate the performance of stream channel erosion control structures constructed by the U.S. Army Corps of Engineers in the highly unstable streams draining the Bluff Line Watersheds of the Lower Mississippi Valley. Construction began in 1977 and completed in 1981. A large number of smaller studies have been conducted including rainfall and runoff relationships, bank stability, bed forms and sediment transport, effect of land use on runoff and sediment loading, enhancement and verification of numerical watershed models and the determination of fine sediment sources using naturally occurring radio nuclides. This watershed has been continuously in operation since 1981 and serves as a unique outdoor laboratory. This watershed is one of the best-instrumented ARS benchmark watersheds where long-term, continuous hydrologic databases are being collected.

\subsection{Mississippi Delta Management Systems Evaluation Area (MDMSEA)}

From 1995 to 2005, the NSL was assigned responsibility to assess the environmental impact and effect of agrichemical applications practices, especially in cotton production, on water quality and ecology of oxbow lakes in the Mississippi Delta and develop alternative practices that would reduce and minimize these effects. Three oxbow lake watersheds (Thighman (1497 ha, 9 ha lake); Beasley (850 ha, 25 ha lake); and Deep Hollow (202 ha, 8 ha lake)) were included in the study, each with its own management practices: conventional farming practices; conventional farming practices in combination with edge-of-field practices (vegetative strips, slotted board risers); and agronomic conservation practices (conservation tillage and cover crops) as well as edge-of-field practices [118]. The results indicated that conservation management practices reduced sediment and non-point source pollutants to the oxbow lakes [119] [120].

\subsection{Conservation Effects Assessment Project (CEAP)}

CEAP is a multi-agency effort that began in 2003 to quantify the environmental effects of conservation practices and programs and develop the science base for managing the agricultural landscape for environmental quality (see also [121]). The program has two components critical to the NSL: 1) Watershed assessment studies to provide detailed quantification of conservation program effects on soil and water quality; and 2) National and regional assessments using watershed scale models and NRCS data bases to estimate the environmental effects and benefits of conservation practices on the landscape. Three of the 14 national watershed assessment studies were assigned to the NSL: Goodwin Creek Experimental Watershed in northern Mississippi, Beasley Lake watershed in the Mississippi Delta [122]-[124], and Topashaw Creek Watershed in the Yalobusha River Basin in Mississippi.

\section{Summary of NSL Scientific Impact}

Considerable effort has been applied to explore soil erosion and, in part, the scientists of the laboratory have played a major role in defining the variables and processes of soil erosion. As a summary to this historic perspective of the NSL, an attempt was made to isolate and characterize the impact of research conducted by scientists from the NSL, specifically focusing on areas of research in which the science presented changed or modified how other researchers or the public in general view soil erosion and sedimentation. To this end, a list of five impact areas has been assembled, including: sediment tracer, soil erodibility, erosion processes by water, erosion technology (equipment and predictive), and soil conservation.

\subsection{Sediment Tracing}

Over the past 45 years, research has shown that Cs-137 can be used effectively and efficiently to study the 
sources and redistribution patterns of soil particles on the landscape. Research primarily focused on sedimentation in lakes and reservoirs [45] [125] [126], provided the basis for the development of these radioisotope techniques that are now widely used around the world. Measurements of radioactive fallout Cs-137 in soils across the landscape can provide timely and quantitative estimates of soil redistribution patterns at many scales and provide independent estimates of soil erosion rates, patterns, redeposition, and sources on the landscape. When compared to a reference site, sites with a loss of Cs-137 are eroding while sites with a gain in Cs-137 are aggrading. The unique ability of Cs-137 to provide a point in time reference of soil erosion gave researchers studying sediment deposition and/or sediment sources a powerful tool for conservation planning.

\subsection{Soil Erodibility}

A fair amount of the early soil erodibility research at the NSL was concerned with USLE K-factor improvement [37] [38] [41] [42]. In particular, the seasonal variations in K values and the impact of freeze-thaw cycles. Later, the focus adjusted from a factor that reflected the combined effects of all soil properties to specific soil properties. Rhoton [127] related soil organic matter to declines in productivity within the southern Mississippi Valley Silty Uplands. In the fragipan soils studied, the yield-limiting factor was water storage capacity. The loss of soil organic matter resulted in unstable soil aggregates and low energy requirements for disruption. Similarly, [128] conducted an 8-yr study on conventional till versus no-till management. The findings suggested that the adoption of no-till practices resulted in improvements to fertility and erodibility parameters within 4-yr.

\subsection{Erosion Processes by Water}

Studies related to erosion mechanics from researchers at the NSL are significant in number; however, a few notable works stand out. Meyer [49] and Foster [47] studied rill erosion as affected by flow rate and canopy, as well as, velocity profiles in stabilized beds. Rainfall effects in interrill erosion [129] and soil roughness changes [63] were also studied, where interrill erosion rates were related to the rain intensity that caused them and changes in soil surface roughness, as related to cumulative rainfall, was described by an exponential decay function. Sediment size distributions in runoff affect sediment transport and deposition and, therefore, studies that quantify the eroded sediment distribution are fundamental. Rhoton [54] developed a laboratory technique to replicate sediment size distributions measured from runoff samples and Meyer [52] determined that aggregation and soil texture effect the size distribution of eroded sediment. Dominant in rill and ephemeral gully erosion, headcuts play a critical role in landscape evolution. Following a series of studies, Bennett [77] presented a detailed look at steady-state soil erosion. Erosion and migration of the headcut were related to removal of the surface seal and erosion of the scour hole was related to the turbulent flow structure impinging jet.

\subsection{Erosion Technology}

Inherent to the work, there will always be some aspect of the soil erosion process that cannot be measured and/or assessment and planning decisions need to be made. With research as the guide, physically- or empirically-based technology must forecast and assist management decisions. In the United States, USLE (1958; [130]) was the first major leap, developed from soil erosion data that was collected beginning in the 1930 by the SCS. USLE is an empirically based conservation-planning tool to predict the long-term average annual soil loss. Several scientists at the NSL were active with USLE research [131]-[133] that included runoff erosivity and variable slope length, slope steepness, and slope length. An important component within USLE research, rainfall simulators were also rigorously tested and improved [134], yielding a portable, variable intensity rainfall simulation apparatus with drop sizes and impact velocities near those of natural rainfall. However, as more research was conducted, physically based soil erosion technology [135], ignited by process research lead to CREAMS [75] and RUSLE [108]. The ever-expanding modeling prediction developments created model structure developmental needs to interface with GIS systems [136] to evaluate watershed conservation planning.

\subsection{Soil Conservation}

Continuing from early observations and traditional soil conservation methods handed down through generations of concerned farmers, the ARS continued to test immerging practices and develop new techniques of soil conservation. Dominant themes included no-till [137], grass hedges [44] [138], and cover crops [139] [140]. Recently, 
vegetated drainage ditches [27]-[29] have been approved in both Mississippi and California as management practices, where farmers are offered incentives for implementation.

Each an integral part of the holistic pattern of soil erosion research and discovery, these accomplishments encourage every one of us to explore every avenue to protect our soil resources.

\section{Acknowledgements}

Many have traveled the halls and laboratories of the NSL. As a laboratory of researchers, all have contributed to the success of the NSL. The success of the laboratory is attributable to perseverance and collaboration with the global community of concerned scientists, to whom much gratitude is owed. The scientists of the NSL thank you and appreciate your continued support.

\section{References}

[1] Bennett, H.H., Smith, H.C., Spann, W.M., Jones, E.M. and Goodman, A.L. (1912) Soil survey of Lauderdale County, Mississippi. Tech. rep., US Department of Agriculture, United States Government Printing Office, Washington DC, $1-56$.

[2] Marbut, C.F., Bennett, H.H., Lapham, J.E. and Lapham, M.H. (1911) Soils of the United States. Bureau of Soils, Bulletin No. 78, US Department of Agriculture, United States Government Printing Office, Washington DC.

[3] Marbut, C.F., Bennett, H.H., Lapham, J.E. and Lapham, M.H. (1913) Soils of the United States. Bureau of Soils, Bulletin No. 96, US Department of Agriculture, United States Government Printing Office, Washington DC.

[4] Mcgee, W.J. (1911) Soil Erosion. USDA Bulletin No. 71, US Department of Agriculture, United States Government Printing Office, Washington DC.

[5] Dabney, C.W. (1915) Soil erosion in the South. USDA Bulletin No. 180, US Department of Agriculture, United States Government Printing Office, Washington DC.

[6] Ramser, C. (1925) Prevention of the Erosion of Farm Lands by Terracing. USDA Bulletin No. 512, US Department of Agriculture, United States Government Printing Office, Washington DC.

[7] Bennett, H.H. and Chapline, W.R. (1928) Soil Erosion: A National Menace. USDA Circular No. 33, US Department of Agriculture, United States Government Printing Office, Washington DC.

[8] Williston, H.L. (1988) The Yazoo-Little Tallahatchie Flood Prevention Project: A History of the Forest Service’s Role. Forestry Report R8-FR8, USDA Forest Service, Oxford.

[9] Langendoen, E.J., Shields, F.D. and Römkens, M.J. (2008) The National Sedimentation Laboratory: 50 Years of Soil and Water Research in a Changing Agricultural Environment. Ecohydrology, 2, 227-234. http://dx.doi.org/10.1002/eco.85

[10] Davis, J.J. (1963) Cesium and Its Relationship to Potassium in Ecology. In: Schultz, V. and Klement, A.W., Eds., Radioecology, Reinhold, New York, 539-556.

[11] Cremers, A., Elsen, A., De Preter, P. and Maes, A. (1988) Quantitative Analysis of Radio-Cesium Retention in Soils. Nature, 335, 247-249. http://dx.doi.org/10.1038/335247a0

[12] Mchenry, J.R., Ritchie, J.C. and Cooper, C.M. (1980) Rates of Recent Sedimentation in Lake Pepin. Water Resources Bulletin, 16, 1049-1059. http://dx.doi.org/10.1111/j.1752-1688.1980.tb02547.x

[13] Ritchie, J.C., Cooper, C.M. and Mchenry, J.R. (1979) Recent Accumulation of Sediment in Lakes in the Bear Creek Watershed in the Mississippi Delta. Southeastern Geology, 20, 173-180.

[14] Ritchie, J.C., Hawks, P.H. and Mchenry, J.R. (1975) Deposition Rates in Valleys Determined Using Fallout Cesium-137. Geological Society of America Bulletin, 86, 1128-1130. http://dx.doi.org/10.1130/0016-7606(1975)86<1128:DRIVDU>2.0.CO;2

[15] Ritchie, J.C., Mchenry, J.R. and Gill, A.C. (1972) Dating Recent Reservoir Sediments. Limnology and Oceanography, 18, 254-263. http://dx.doi.org/10.4319/lo.1973.18.2.0254

[16] Ritchie, J.C. and Ritchie, C.A. (2008) Bibliography of Publications of ${ }^{137}$ Cesium Studies Related to Soil Erosion and Sediment Deposition. http://www.ars.usda.gov/Main/docs.htm?docid=16884

[17] Wren, D.G., Davidson, G.R., Walker, W.G. and Galicki, S. (2008) The Evolution of an Oxbow Lake in the Mississippi Alluvial Floodplain. Journal of Soil and Water Conservation, 63, 129-135. http://dx.doi.org/10.2489/jswc.63.3.129

[18] Cooper, C.M. (1987) Benthos in Bear Creek, Mississippi: Effects of Habitat Variation and Agricultural Sediments. Journal of Freshwater Ecology, 4, 101-113. http://dx.doi.org/10.1080/02705060.1987.9665167

[19] Cooper, C.M. and Knight, S.S. (1987) Fisheries in Man-Made Pools below Grade-Control Structures and in Naturally Occurring Scour Holes of Unstable Streams. Journal of Soil and Water Conservation, 42, 370-373. 
[20] Cooper, C.M. (1993) Biological Effects of Agriculturally Derived Surface Water Pollutants on Aquatic Systems-A Review. Journal of Environmental Quality, 22, 402-408. http://dx.doi.org/10.2134/jeq1993.00472425002200030003x

[21] Cooper, C.M., Dendy, F.E., Mchenry, J.R. and Ritchie, J.C. (1987) Residual Pesticide Concentrations in Bear Creek, Mississippi, 1976 to 1979. Journal of Environmental Quality, 16, 69-72. http://dx.doi.org/10.2134/jeq1987.00472425001600010014x

[22] Cooper, C.M., Smiley, P.C., Wiggington, J.D., Knight, S.S. and Kallies, K.W. (1997) Vertebrate Use of Habitats Created by Installation of Field-Scale Erosion Control Structures. Journal of Freshwater Ecology, 12, 199-207. http://dx.doi.org/10.1080/02705060.1997.9663527

[23] Moore, M.T., Rodgers, J.H., Cooper, C.M. and Smith, S. (2000) Constructed Wetlands for Mitigation of Atrazine-Associated Agricultural Runoff. Environmental Pollution, 110, 393-399. http://dx.doi.org/10.1016/S0269-7491(00)00034-8

[24] Shields, F.D., Knight, S.S. and Cooper, C.M. (1995) Use of the Index of Biotic Integrity to Assess Physical Habitat Degradation in Warm-Water Streams. Hydrobiologia, 312, 191-208. http://dx.doi.org/10.1007/BF00015512

[25] Shields, F.D., Knight, S.S. and Cooper, C.M. (2000) Cyclic Perturbation of Lowland River Channels and Ecological Response. Regulated Rivers: Research and Management, 16, 307-325. http://dx.doi.org/10.1002/1099-1646(200007/08)16:4<307::AID-RRR582>3.0.CO;2-2

[26] Shields, F.D., Smiley, P.C. and Cooper, C.M. (2002) Design and Management of Edge-of-Field Water Control Structures for Ecological Benefits. Journal of Soil and Water Conservation, 57, 151-157.

[27] Moore, M.T., Bennett, E.R., Cooper, C.M., Smith, S., Shields, F.D., Milam, C.D. and Farris, J.L. (2001) Transport and Fate of Atrazine and Lambda-Cyhalothrin in an Agricultural Drainage Ditch in the Mississippi Delta, USA. Agriculture, Ecosystems and Environment, 87, 309-314. http://dx.doi.org/10.1016/S0167-8809(01)00148-7

[28] Moore, M.T., Denton, D.L., Cooper, C.M., Wrysinski, J., Miller, J.L., Werner, I., Horner, G., Crane, D., Holcomb, D.B. and Huddleston III, G.M. (2011) Use of Vegetated Agricultural Drainage Ditches to Decrease Pesticide Transport from Tomato and Alfalfa Fields in California, USA. Environmental Toxicology and Chemistry, 30, 1044-1049. http://dx.doi.org/10.1002/etc.474

[29] Moore, M.T., Kröger, R., Farris, J.L., Locke, M.A., Bennett, E.R., Denton, D.L. and Cooper, C.M. (2011) From Vegetated Ditches to Rice Fields: Thinking outside the Box for Pesticide Mitigation. In: Goh, K.S., Bret, B.L., Potter, T.L. and Gan, J., Eds., Pesticide Mitigation Strategies for Surface Water Quality, American Chemical Society Symposium Series 1075, American Chemical Society, Washington DC, 29-37.

[30] Kröger, R., Cooper, C.M. and Moore, M.T. (2008) A Preliminary Study of an Alternative Strategy in Surface Drainage Ditches: Low-Grade Weirs. Agricultural Water Management, 95, 678-684. http://dx.doi.org/10.1016/j.agwat.2008.01.006

[31] Meyer, L.D. and Harmon, W.C. (1992) Soil Erosion Varies during the Crop Year. Transactions of the American Society of Agricultural Engineers, 35, 459-464. http://dx.doi.org/10.13031/2013.28621

[32] Mutchler, C.K. and Mcdowell, L.L. (1990) Soil Loss from Cotton with Winter Cover Crops. Transactions of the American Society of Agricultural Engineers, 33, 432-436. http://dx.doi.org/10.13031/2013.31347

[33] Rhoton, F.E. (1990) Soybean Yield Response to Various Depths of Erosion on a Fragipan Soil. Soil Science Society of America Journal, 54, 1073-1079. http://dx.doi.org/10.2136/sssaj1990.03615995005400040024x

[34] Woodburn, R. (1945) A Comparison of Erosion Losses after Turning Legumes and Non-Legumes. Agricultural Engineering, 26, 247-248.

[35] Grissinger, E.H. (1966) Resistance of Selected Clay Systems to Erosion by Water. Water Resources Research, 2, 131138. http://dx.doi.org/10.1029/WR002i001p00131

[36] Grissinger, E.H., Little, W.C. and Murphey, J.B. (1981) Erodibility of Streambank Materials at Low Cohesion. Transactions of the American Society of Agricultural Engineers, 24, 624-630. http://dx.doi.org/10.13031/2013.34311

[37] Meyer, L.D. and Harmon, W.C. (1984) Susceptibility of Agricultural Soils to Interrill Erosion. Soil Science Society of America Journal, 48, 1152-1157. http://dx.doi.org/10.2136/sssaj1984.03615995004800050040x

[38] Mutchler, C.K. and Carter, C.E. (1983) Soil Erodibility Variation during the Year. Transactions of the American Society of Agricultural Engineers, 26, 1102-1104.

[39] Römkens, M.J., Nelson, D.W. and Roth, C.B. (1975) Soil Erosion on Selected High Clay Subsoils. Journal of Soil and Water Conservation, 30, 173-176.

[40] Woodburn, R. (1948) The Effect of Structural Condition on Soil Detachment by Raindrop Action. Agricultural Engineering, 29, 154-156.

[41] Young, R.A. and Mutchler, C.K. (1977) Erodibility of Some Minnesota Soils. Journal of Soil and Water Conservation, 32, 180-182. 
[42] Young, R.A., Römkens, M.J. and Mccool, D.K. (1990) Temporal Variations in Soil Erodibility. Catena Supplement, 17, 41-53.

[43] Young, R.A. and Mutchler, C.K. (1969) Effect of Slope Shape on Erosion and Runoff. Transactions of the American Society of Agricultural Engineers, 12, 231-233.

[44] Dabney, S.M., Meyer, L.D., Harmon, W.C., Alonso, C.V. and Foster, G.R. (1995) Depositional Patterns of Sediment Trapped by Grass Hedges. Transactions of the American Society of Agricultural Engineers, 38, 1719-1729. http://dx.doi.org/10.13031/2013.27999

[45] Mchenry, J.R., Ritchie, J.C. and Gill, A.C. (1973) Accumulation of Fallout Cesium 137 in Soils and Sediments in Selected Watersheds. Water Resources Research, 9, 676-686. http://dx.doi.org/10.1029/WR009i003p00676

[46] Römkens, M.J., Johnson, C.B. and Nelson, D.W. (1978) Soil Erosion Control on Construction Sites with Portland Cement. Journal of Soil and Water Conservation, 33, 232-235.

[47] Foster, G.R., Huggins, L.F. and Meyer, L.D. (1984) A Laboratory Study of Rill Hydraulics: I. Velocity Relationships. Transactions of the American Society of Agricultural Engineers, 27, 790-796. http://dx.doi.org/10.13031/2013.32873

[48] Foster, G.R., Huggins, L.F. and Meyer, L.D. (1984) A Laboratory Study of Rill Hydraulics: II. Shear Stress Relationships. Transactions of the American Society of Agricultural Engineers, 27, 797-804. http://dx.doi.org/10.13031/2013.32874

[49] Meyer, L.D., Foster, G.R. and Nikolov, S. (1975) Effect of Flow Rate and Canopy on Rill Erosion. Transactions of the American Society of Agricultural Engineers, 18, 905-911. http://dx.doi.org/10.13031/2013.36705

[50] Meyer, L.D., Harmon, W.C. and Mcdowell, L.L. (1980) Sediment Sizes Eroded from Crop Row Sideslopes. Transactions of the American Society of Agricultural Engineers, 23, 891-898. http://dx.doi.org/10.13031/2013.34682

[51] Rhoton, F.E., Meyer, L.D. and Whisler, F.D. (1983) Response of Aggregated Sediment to Runoff Stresses. Transactions of the American Society of Agricultural Engineers, 26, 1476-1478. http://dx.doi.org/10.13031/2013.34153

[52] Meyer, L.D., Line, D.E. and Harmon, W.C. (1992) Size Characteristics of Sediment from Agricultural Soils. Journal of Soil and Water Conservation, 47, 107-111.

[53] Meyer, L.D., Willoughby, W.E., Whisler, F.D. and Rhoton, F.E. (1983) Predicting Size Distributions of Sediment Eroded from Aggregated Soils. Transactions of the American Society of Agricultural Engineers, 26, 486-490. http://dx.doi.org/10.13031/2013.33962

[54] Rhoton, F.E., Meyer, L.D. and Whisler, F.D. (1982) A Laboratory Method for Predicting the Size Distribution of Sediment Eroded from Surface Soils. Soil Science Society of America Journal, 46, 1259-1263. http://dx.doi.org/10.2136/sssaj1982.03615995004600060027x

[55] Parlange, J.Y., Lisle, I.G., Prasad, S.N. and Römkens, M.J. (1984) Wetting Front Analysis of the Nonlinear Diffusion Equation. Water Resources Research, 20, 636-638. http://dx.doi.org/10.1029/WR020i005p00636

[56] Prasad, S.N. and Römkens, M.J. (1982) An Approximate Integral Solution of Vertical Infiltration under Changing Boundary Conditions. Water Resources Research, 18, 1022-1028. http://dx.doi.org/10.1029/WR018i004p01022

[57] Wells, R.R., Dicarlo, D.A., Steenhuis, T.S., Parlange, J.Y., Römkens, M.J. and Prasad, S.N. (2003) Infiltration and Surface Geometry Features of a Swelling Soil Following Successive Simulated Rainstorms. Soil Science Society of America Journal, 67, 1344-1351. http://dx.doi.org/10.2136/sssaj2003.1344

[58] Mermut, A.R., Luk, S.H., Römkens, M.J. and Poesen, J.W. (1980) Micromorphological and Mineralogical Components of Surface Sealing in Loess Soils from Different Geographic Regions. Geoderma, 66, 71-84. http://dx.doi.org/10.1016/0016-7061(94)00053-D

[59] Römkens, M.J., Prasad, S.N. and Parlange, J.Y. (1990) Surface Seal Development in Relation to Rainstorm Intensity. Catena Supplement, 17, 1-11.

[60] Lehrsch, G.A., Whisler, F.D. and Römkens, M.J. (1988) Spatial Variation of Parameters Describing Soil Surface Roughness. Soil Science Society of America Journal, 52, 311-319. http://dx.doi.org/10.2136/sssaj1988.03615995005200020002x

[61] Römkens, M.J., Helming, K. and Prasad, S.N. (2001) Soil Erosion under Different Rainfall Intensities, Surface Roughness, and Soil Water Regimes. Catena, 46, 103-123.

[62] Römkens, M.J. and Prasad, S.N. (1992) A Spectral Series Approach to Infiltration for Crusted and Non-Crusted Soils. In: Sumner, M.E. and Stewart, B.A., Eds., Soil Crusting-Chemical and Physical Processes, Advances in Soil Science, Lewis Publishers, CRS Press, Inc., Boca Raton, 151-178.

[63] Römkens, M.J. and Wang, J.Y. (1987) Soil Roughness Changes from Rainfall. Transactions of the American Society of Agricultural Engineers, 30, 101-107. http://dx.doi.org/10.13031/2013.30409

[64] Bertrand, A.R. and Woodburn, R. (1964) A Fresh Look at Gully Erosion in the South. Journal of Soil and Water Conservation, 19, 173-175. 
[65] Miller, C.R., Woodburn, R. and Turner, H.R. (1962) Upland Gully Sediment Production. International Association of Scientific Hydrology Symposium on Land Erosion, 59, 83-104.

[66] Woodburn, R. (1949) Science Studies a Gully. Soil Conservation, 15, 11-13.

[67] Foster, G.R. (1982) Modeling the Erosion Process. In: Haan, C.T., Johnson, H.P. and Brakensiek, D.L., Eds., Hydrologic Modeling of Small Watersheds, ASAE Monograph No. 5, American Society of Agricultural Engineers, St. Joseph, 297-380.

[68] Lane, L.J. and Foster, G.R. (1980) Concentrated Flow Relationships. In: Knisel, W.G., Ed., Creams: A Field Scale Model for Chemicals, Runoff, and Erosion from Agricultural Management Systems, Conservation Research Report 26, US Department of Agriculture, Washington DC, 474-485.

[69] Thorne, C.R. (1984) Prediction of Soil Loss Due to Ephemeral Gullies in Arable Fields. Report CER83-84CRT, Colorado State University, Ft. Collins.

[70] Thorne, C.R., Grissinger, E.H. and Murphey, J.B. (1984) Field Study of Ephemeral Cropland Gullies in Northern Mississippi. Proceedings of the ASAE Winter Meeting, Paper No. 84-2550, New Orleans, 11 December 1984, 11 p.

[71] Thorne, C.R. and Zevenbergen, L.W. (1990) Prediction of Ephemeral Gully Erosion on Cropland in the South-Eastern United States. In: Boardman, J., Dearing, J.A. and Foster, I.D.L., Eds., Soil Erosion on Agricultural Land, Wiley and Sons, Hoboken, 447-460.

[72] Zevenbergen, L.W. and Thorne, C.R. (1987) Quantitative Analysis of Land Surface Topography. Earth Surface Processes and Landforms, 12, 47-56. http://dx.doi.org/10.1002/esp.3290120107

[73] Ritchie, J.C., Grissinger, E.H., Murphey, J.B. and Garbrecht, J.D. (1994) Measuring Channel and Gully Cross-Sections with an Airborne Laser Altimeter. Hydrological Processes, 8, 237-243. http://dx.doi.org/10.1002/hyp.3360080305

[74] Foster, G.R. (1986) Understanding Ephemeral Gully Erosion. In: Committee on Conservation Needs and Opportunities, Ed., Assessing the Natural Resource Inventory, Soil Conservation Service, Board of Agriculture, National Research Council, National Academy Press, Washington DC, 90-125.

[75] Foster, G.R., Lane, L.J., Nowlin, J.D., Laflen, L.M. and Young, R.A. (1980) A Model to Estimate the Sediment Yield from Field-Sized Areas: Development of Model and Selection of Parameter Values. In: Knisel, W.G., Ed., Creams: A Field Scale Model for Chemicals, Runoff, and Erosion from Agricultural Management Systems, Conservation Research Report 26, US Department of Agriculture, Washington DC, pp. 36-64 and 193-281.

[76] Bennett, S.J. (1999) Effect of Slope on the Growth and Migration of Headcuts in Rills. Geomorphology, 30, $273-290$. http://dx.doi.org/10.1016/S0169-555X(99)00035-5

[77] Bennett, S.J., Alonso, C.V., Prasad, S.N. and Römkens, M.J. (2000) Experiments on Headcut Growth and Migration in Concentrated Flows Typical of Upland Areas. Water Resources Research, 36, 1911-1922. http://dx.doi.org/10.1029/2000WR900067

[78] Bennett, S.J. and Casalí, J. (2001) Effect of Initial Step Height on Headcut Development in Upland Concentrated Flows. Water Resources Research, 37, 1475-1484. http://dx.doi.org/10.1029/2000WR900373

[79] Dabney, S.M., Shields Jr., F.D., Temple, D.M. and Langendoen, E.J. (2004) Erosion Processes in Gullies Modified by Establishing Grass Hedges. Transactions of the American Society of Agricultural Engineers, 47, 1561-1571. http://dx.doi.org/10.13031/2013.17634

[80] Gordon, L.M., Bennett, S.J., Wells, R.R. and Alonso, C.V. (2007) Effect of Soil Stratification on the Development and Migration of Headcuts in Upland Concentrated Flows. Water Resources Research, 43, Article ID: W07412. http://dx.doi.org/10.1029/2006WR005659

[81] Wells, R.R., Alonso, C.V. and Bennett, S.J. (2009) Morphodynamics of Headcut Development and Soil Erosion in Upland Concentrated Flows. Soil Science Society of America Journal, 73, 521-530. http://dx.doi.org/10.2136/sssaj2008.0007

[82] Wells, R.R., Bennett, S.J. and Alonso, C.V. (2009) Effect of Soil Texture, Tailwater Height, and Pore-Water Pressure on the Morphodynamics of Migrating Headcuts in Upland Concentrated Flows. Earth Surface Processes and Landforms, 34, 1867-1877. http://dx.doi.org/10.1002/esp.1871

[83] Wells, R.R., Bennett, S.J. and Alonso, C.V. (2010) Modulation of Headcut Soil Erosion in Rills Due to Upstream Sediment Loads. Water Resources Research, 46, Article ID: W12531. http://dx.doi.org/10.1029/2010WR009433

[84] Wells, R.R., Momm, H.G., Rigby, J.R., Bennett, S.J., Bingner, R.L. and Dabney, S.M. (2013) An Empirical Investigation of Gully Widening Rates in Upland Concentrated Flows. Catena, 101, 114-121. http://dx.doi.org/10.1016/j.catena.2012.10.004

[85] Lu, Z. and Wilson, G.V. (2013) Acoustic Measurements of Soil Pipeflow and Internal Erosion. Soil Science Society of America Journal, 76, 853-866. http://dx.doi.org/10.2136/sssaj2011.0308

[86] Wilson, G.V. (2011) Understanding Soil-Pipeflow and Its Role in Ephemeral Gully Erosion. Hydrological Processes, 25, 2354-2364. http://dx.doi.org/10.1002/hyp.7998 
[87] Wilson, G.V., Nieber, J., Sidle, R.C. and Fox, G.A. (2013) Internal Erosion during Soil Pipeflow: State of Science for Experimental and Numerical Analysis. Transactions of the American Society of Agricultural and Biological Engineers, 56, 465-478.

[88] Alonso, C.V., Bennett, S.J. and Stein, O.R. (2002) Predicting Headcut Erosion and Migration in Upland Flows. Water Resources Research, 38, 39.1-39.15. http://dx.doi.org/10.1029/2001WR001173

[89] Bernard, J., Bingner, R.L., Dabney, S.M., Langendoen, E.J., Lemunyon, J., Merkel, W., Theurer, F., Wells, R.R., Widman, N. and Wilson, G.V. (2010) Ephemeral Gully Erosion a Natural Resource Concern. Laboratory Publication Report 69, US Department of Agriculture, Agricultural Research Service, National Sedimentation Laboratory, Oxford, MS.

[90] Kuhnle, R.A. (1993) Incipient Motion of Sand-Gravel Sediment Mixtures. Journal of Hydraulic Engineering, 119, 1400-1415. http://dx.doi.org/10.1061/(ASCE)0733-9429(1993)119:12(1400)

[91] Coleman, N.L. (1970) Flume Studies of the Sediment Transfer Coefficient. Water Resources Research, 6, 801-809. http://dx.doi.org/10.1029/WR006i003p00801

[92] Willis, J.C. (1979) Suspended Load from Error-Function Models. ASCE Journal of the Hydraulics Division, 105, 801816.

[93] Willis, J.C. (1985) Near-Bed Velocity Distribution. Journal of Hydraulic Engineering, 111, 741-753. http://dx.doi.org/10.1061/(ASCE)0733-9429(1985)111:5(741)

[94] Willis, J.C. (1993) Distributions of Flow Velocity and Suspended Sediment. In: Wang, S.S.Y., Ed., Advances in Hydro-Science and Engineering, The University of Mississippi, Oxford, MS, 664-671.

[95] Willis, J.C. (1968) A Lag-Deviation Method for Analyzing Channel Bed Forms. Water Resources Research, 4, 13291334. http://dx.doi.org/10.1029/WR004i006p01329

[96] Willis, J.C. and Bolton, G.G. (1979) Statistical Analysis of Concentration Records. ASCE Journal of the Hydraulics Division, 105, 10-15.

[97] Willis, J.C. and Kennedy, J.F. (1977) Sediment Discharge of Alluvial Streams Calculated from Bedform Statistics. Report No. 202, Iowa Institute of Hydraulic Research, Iowa City.

[98] Kuhnle, R.A., Alonso, C.V. and Shields, F.D. (1999) Geometry of Scour Holes Associated with 90 Degree Spur Dikes. Journal of Hydraulic Engineering, 125, 972-978. http://dx.doi.org/10.1061/(ASCE)0733-9429(1999)125:9(972)

[99] Kuhnle, R.A., Alonso, C.V. and Shields, F.D. (2002) Local Scour Associated with Angled Spur Dikes. Journal of Hydraulic Engineering, 128, 1087-1093. http://dx.doi.org/10.1061/(ASCE)0733-9429(2002)128:12(1087)

[100] Coleman, N.L. (1975) An Attempt to Predict Channel Sediment Transport Capacity with Similitude Principles. Proceedings of the Sediment-Yield Workshop, USDA Sedimentation Laboratory, Oxford, MS, 28-30 November 1972, 231240.

[101] Willis, J.C. and Coleman, N.L. (1969) Unification of Data on Sediment Transport in Flumes by Similitude Principles. Water Resources Research, 5, 1330-1336. http://dx.doi.org/10.1029/WR005i006p01330

[102] Prasad, S.N., Pal, D. and Römkens, M.J. (2000) Wave Formation on a Shallow Layer of Flowing Grains. Journal of Fluid Mechanics, 413, 89-110. http://dx.doi.org/10.1017/S0022112000008296

[103] Prasad, S.N., Suryadevara, M.R. and Römkens, M.J. (2009) Grain Transport Mechanics in Shallow Overland Flow. Ecohydrology, 2, 248-256. http://dx.doi.org/10.1002/eco.64

[104] Römkens, M.J., Suyadevara, M.R. and Prasad, S.N. (2013) A Phenomenological Study of Sediment Transport in Shallow Overland Flow. Transactions of the American Society of Agricultural and Biological Engineers, 56, 515-522.

[105] Kuhnle, R.A. and Wren, D.G. (2006) Lateral Variations in Suspended Sediment Concentration over Dunes. Journal of Hydraulic Engineering, 132, 1341-1346. http://dx.doi.org/10.1061/(ASCE)0733-9429(2006)132:12(1341)

[106] Kuhnle, R.A., Wren, D.G. and Chambers, J.P. (2007) Prediction of the Grain Size of Suspended Sediment: Implications for Calculating Suspended Sediment Concentrations Using Single Frequency Acoustic Backscatter. International Journal of Sediment Research, 22, 1-15.

[107] Wren, D.G., Kuhnle, R.A. and Wilson, C.G. (2007) Measurements of the Relationship between Turbulence and Sediment in Suspension over Mobile Sand Dunes in a Laboratory Flume. Journal of Geophysical Research, 112, Article ID: F03009. http://dx.doi.org/10.1029/2006JF000683

[108] Renard, K.G., Foster, G.R., Weesies, G.A., Mccool, D.K., Yoder, D.C. and Coordinators (1997) Predicting Soil Erosion by Water: A Guide to Conservation Planning with the Revised Universal Soil Loss Equation (RUSLE). Agriculture Handbook No. 703, US Department of Agriculture, Washington DC, 404 p.

[109] Bingner, R.L. and Theurer, F.D. (2001) AGNPS 98: A Suite of Water Quality Models for Watershed Use. Proceedings of the Sediment: Monitoring, Modeling, and Managing, 7th Federal Interagency Sedimentation Conference, Reno, 25-29 March 2001, VII-1-VII-8. 
[110] Langendoen, E.J. (2000) CONCEPTS-Conservational Channel Evolution and Pollutant Transport System: Stream Corridor Version 1.0. Research Report No. 16, US Department of Agriculture, Agricultural Research Service, National Sedimentation Laboratory, Oxford, MS.

[111] Langendoen, E.J. and Alonso, C.V. (2008) Modeling the Evolution of Incised Streams: I. Model Formulation and Validation of Flow and Streambed Evolution Components. Journal of Hydraulic Engineering, 134, 749-762. http://dx.doi.org/10.1061/(ASCE)0733-9429(2008)134:6(749)

[112] Langendoen, E.J. and Simon, A. (2008) Modeling the Evolution of Incised Streams: II. Streambank Erosion. Journal of Hydraulic Engineering, 134, 905-915. http://dx.doi.org/10.1061/(ASCE)0733-9429(2008)134:7(905)

[113] Alonso, C.V. and Bingner, R.L. (2000) Goodwin Creek Experimental Watershed: A Unique Field Laboratory. Journal of Hydraulic Engineering, 126, 174-177. http://dx.doi.org/10.1061/(ASCE)0733-9429(2000)126:3(174)

[114] Bingner, R.L., Kuhnle, R.A. and Alonso, C.V. (2007) Goodwin Creek Experimental Watershed: A Historical Perspective. In: Rogers, J.R., Ed., Environmental and Water Resources: Milestones in Engineers History, ASCE, Reston, Virginia, 113-117.

[115] Kuhnle, R.A., Bennett, S.J., Alonso, C.V., Bingner, R.L. and Langendoen, E.J. (2000) Sediment Transport Processes in Agricultural Watersheds. International Journal of Sediment Research, 15, 182-197.

[116] Kuhnle, R.A., Bingner, R.L., Alonso, C.V., Wilson, C.G. and Simon, A. (2008) Conservation Practice Effects on Sediment Load in the Goodwin Creek Experimental Watershed. Journal of Soil and Water Conservation, 63, 496-503. http://dx.doi.org/10.2489/jswc.63.6.496

[117] Kuhnle, R.A., Bingner, R.L., Foster, G.R. and Grissinger, E.H. (1993) Effect of Land Use Changes on Sediment Transport in Goodwin Creek. Water Resources Research, 32, 3189-3196. http://dx.doi.org/10.1029/96WR02104

[118] Locke, M.A. (2004) Mississippi Delta Management Systems Evaluation Area: Overview of Water Quality Issues on a Watershed Scale. In: Nett, M.T., Locke, M.A. and Pennington, D.A., Eds., Water Quality Assessments in the Mississippi Delta: Regional Solutions, National Scope, ACS Symposium Series 877, 1-15.

[119] Locke, M.A., Knight, S.S., Smith, S., Cullum, R.F., Zablotowicz, R.M., Yuan, Y. and Bingner, R.L. (2008) Environmental Quality Research in Beasley Lake Watershed, 1995-2007: Succession from Conventional to Conservation Practices. Journal of Soil and Water Conservation, 63, 430-442. http://dx.doi.org/10.2489/jswc.63.6.430

[120] Zablotowicz, R.M., Locke, M.A., Krutz, L.J., Lerch, R.N., Lizotte, R.E., Knight, S.S., Gordon, R.E. and Steinriede, R.W. (2006) Influence of Watershed Management System on Herbicide Concentration in Mississippi Delta Oxbow Lakes. Science of the Total Environment, 370, 552-560. http://dx.doi.org/10.1016/j.scitotenv.2006.08.023

[121] Duriancik, L.F., Bucks, D., Dobrowolski, J.P., Drewes, T., Eckles, S.D., Jolley, L., Kellogg, R.L., Lund, D., Makuch, J.R., Oneill, M.P., Rewa, C.A., Wallbridge, M.R., Parry, R. and Weltz, M.A. (2008) The First Five Years of the Conservation Effects Assessment Project. Journal of Soil and Water Conservation, 63, 185A-197A. http://dx.doi.org/10.2489/jswc.63.6.185A

[122] Lizotte, R.E., Knight, S.S., Locke, M.A. and Bingner, R.L. (2013) Influence of Integrated Watershed-Scale Agricultural Conservation Practices on Lake Water Quality. Journal of Soil and Water Conservation, 69, 160-170. http://dx.doi.org/10.2489/jswc.69.2.160

[123] Lizotte, R.E., Knight, S.S., Locke, M.A. and Steinriede, R.W. (2012) Ten-Year Assessment of Agriculture Management and Landuse Practices on Pesticide Loads and Risk to Aquatic Biota of an Oxbow Lake in the Mississippi Delta, USA. In: Hendriks, B.P., Ed., Agricultural Research Updates, Volume 2, Nova Science Publishers, Hauppauge, 349371.

[124] Lizotte, R.E., Knight, S.S., Locke, M.A., Steinriede, R.W., Testa, S. and Bryant, C. (2012) Water Quality Monitoring of an Agricultural Watershed Lake: The Effectiveness of Agricultural Best Management Practices. In: Hernandez, S. and Brebbia, C.A., Eds., Design and Nature IV: Comparing Design in Nature with Science and Engineering (WIT Transactions in Ecology and the Environment Series), Volume 160, WIT Press, England, 283-294.

[125] Ritchie, J.C., Mchenry, J.R. and Gill, A.C. (1974) Fallout Cs-137 in Soils and Sediments in 3 Small Watersheds. Ecology, 55, 887-890. http://dx.doi.org/10.2307/1934426

[126] Ritchie, J.C., Spraberr, J.A. and Mchenry, J.R. (1974) Estimating Soil Erosion from Redistribution of Fallout Cs-137. Soil Science Society of America Journal, 38, 137-139. http://dx.doi.org/10.2136/sssaj1974.03615995003800010042x

[127] Rhoton, F.E. and Tyler, D.D. (1990) Erosion-Induced Changes in the Properties of a Fragipan Soil. Soil Science Society of America Journal, 54, 223-228. http://dx.doi.org/10.2136/sssaj1990.03615995005400010035x

[128] Rhoton, F.E. (2000) Influence of Time on Soil Response to No-Till Practices. Soil Science Society of America Journal, 64, 700-709. http://dx.doi.org/10.2136/sssaj2000.642700x

[129] Meyer, L.D. (1981) Sediment Sizes Eroded from Crop Row Sideslopes. Transactions of the American Society of Agricultural Engineers, 24, 1472-1475. 
[130] Wischmeier, W.H. and Smith, D.D. (1965) Predicting Rainfall-Erosion Losses from Cropland East of the Rocky Mountains. Agricultural Handbook No. 282, United States Department of Agriculture, Washington DC, 47 p.

[131] Foster, G.R., Meyer, L.D. and Onstad, C.A. (1977) Erosion Equation Derived from Basic Erosion Principles. Transactions of the American Society of Agricultural Engineers, 20, 678-682. http://dx.doi.org/10.13031/2013.35627

[132] Mccool, D.K., Brown, L.C. and Foster, G.R. (1987) Revised Slope Steepness Factor for the Universal Soil Loss Equation. Transactions of the American Society of Agricultural Engineers, 30, 1387-1396. http://dx.doi.org/10.13031/2013.30576

[133] Mccool, D.K., Foster, G.R., Mutchler, C.K. and Meyer, L.D. (1989) Revised Slope Lengths Factor for the Universal Soil Loss Equation. Transactions of the American Society of Agricultural Engineers, 32, 1571-1576. http://dx.doi.org/10.13031/2013.31192

[134] Meyer, L.D. and Harmon, W.C. (1979) Multiple-Intensity Rainfall Simulator for Erosion Research on Row Sideslopes. Transactions of the American Society of Agricultural Engineers, 22, 100-103. http://dx.doi.org/10.13031/2013.34973

[135] Foster, G.R. Meyer, L.D. and Onstad, C.A. (1977) Runoff Erosivity Factor and Variable Slope Length Exponents for Soil Loss Estimates. Transactions of the American Society of Agricultural Engineers, 20, 683-687. http://dx.doi.org/10.13031/2013.35628

[136] Bingner, R.L., Garbrecht, J. and Arnold, J.G. (1977) Effect of Watershed Subdivision on Simulation Runoff and Fine Sediment Yield. Transactions of the American Society of Agricultural Engineers, 40, 1329-1335. http://dx.doi.org/10.13031/2013.21391

[137] Mcgregor, K.C., Greer, J.D. and Gurley, G.E. (1975) Erosion Control with No-Till Cropping Practices. Transactions of the American Society of Agricultural Engineers, 18, 918-920. http://dx.doi.org/10.13031/2013.36707

[138] Meyer, L.D., Dabney, S.M. and Harmon, W.C. (1995) Sediment Trapping Effectiveness of Stiff Grass Hedges. Transactions of the American Society of Agricultural Engineers, 38, 809-815. http://dx.doi.org/10.13031/2013.27895

[139] Dabney, S.M. (1998) Cover Crop Impacts on Watershed Hydrology. Journal of Soil and Water Conservation, 53, 207213.

[140] Dabney, S.M., Delgado, J.A. and Reeves, D.W. (2001) Using Winter Cover Crops to Improve Soil and Water Quality. Communications in Soil Science and Plant Analysis, 32, 1221-1250. http://dx.doi.org/10.1081/CSS-100104110 
Scientific Research Publishing (SCIRP) is one of the largest Open Access journal publishers. It is currently publishing more than 200 open access, online, peer-reviewed journals covering a wide range of academic disciplines. SCIRP serves the worldwide academic communities and contributes to the progress and application of science with its publication.

Other selected journals from SCIRP are listed as below. Submit your manuscript to us via either submit@scirp.org or Online Submission Portal.
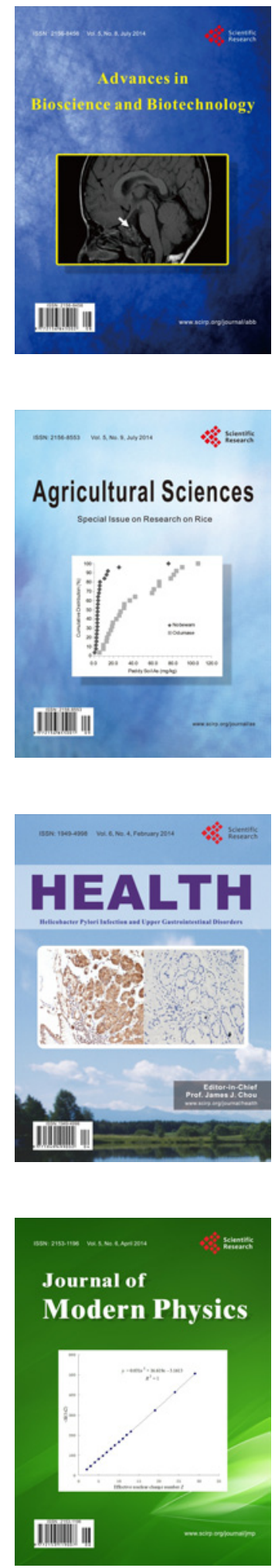
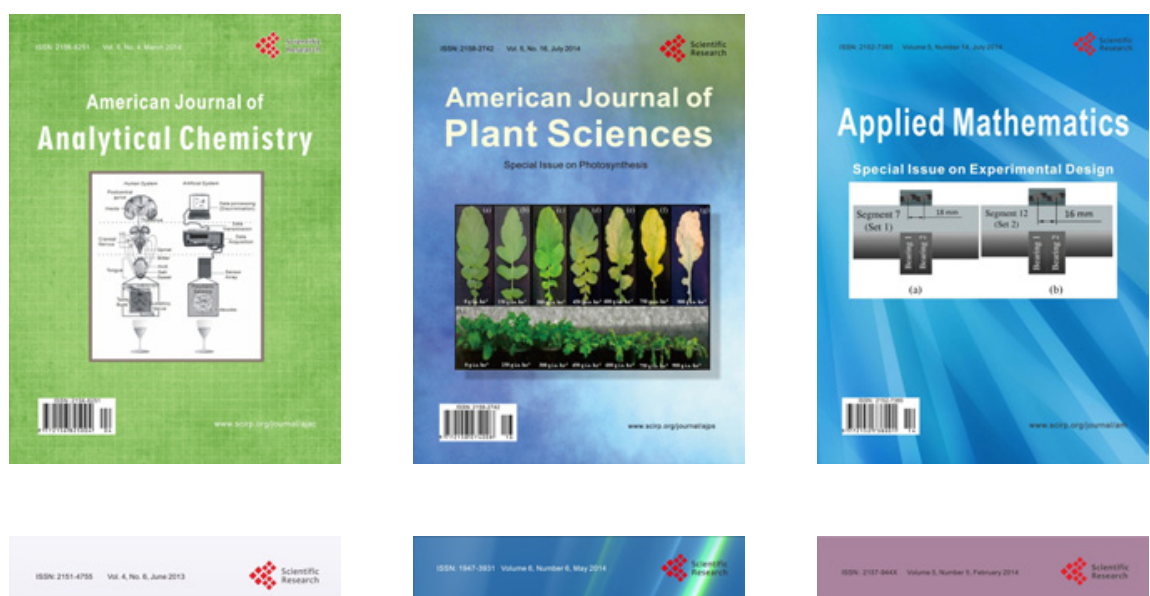

Creative Education
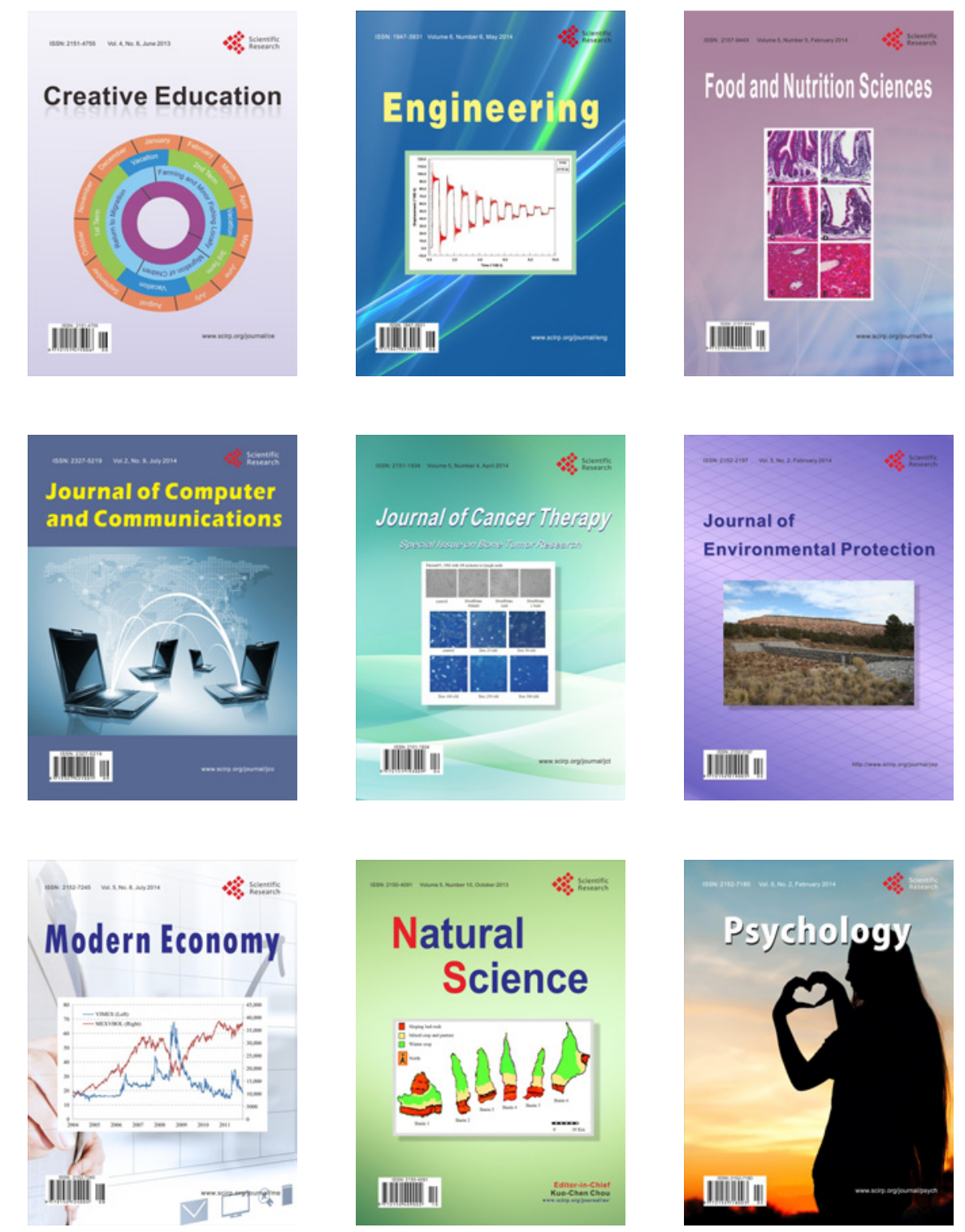